Management international

International Management

Gestiòn Internacional

\title{
The effect of social and environmental disclosure on companies' market value
}

L'effet de la divulgation sociale et environnementale sur la

valeur de marché des entreprises

El efecto de divulgación social y ambiental en el valor de

mercado de las empresas

Jocelyn Husser et Frédérique Evraert-Bardinet

Volume 19, numéro 1, automne 2014

URI : https://id.erudit.org/iderudit/1028490ar

DOI : https://doi.org/10.7202/1028490ar

Aller au sommaire du numéro

\section{Éditeur(s)}

HEC Montréal

Université Paris Dauphine

\section{ISSN}

1206-1697 (imprimé)

1918-9222 (numérique)

Découvrir la revue

Citer cet article

Husser, J. \& Evraert-Bardinet, F. (2014). The effect of social and environmental disclosure on companies' market value. Management international /

International Management / Gestiòn Internacional, 19(1), 61-84.

https://doi.org/10.7202/1028490ar

\section{Résumé de l'article}

La recherche étudie la relation entre la valeur de marché, la valeur comptable et les informations relatives à la responsabilité sociale des entreprises (RSE) et au développement durable (DD) pour les années 2007-2008. Cet article mobilise des scores de divulgation sociale et environnementale provenant d'une grille d'analyse structurale basée sur les rapports de 120 entreprises. Les résultats montrent que les investisseurs mesurent la performance à court terme d'une entreprise en utilisant des informations sur la qualité de la gestion environnementale de l'entreprise. Dans le même temps, la communication sociale de l'entreprise concernant la qualité de la gestion du personnel influence sa performance à court terme et à long terme.
Tous droits réservés (c) Management international / International Management / Gestión Internacional, 2014
Ce document est protégé par la loi sur le droit d'auteur. L'utilisation des services d'Érudit (y compris la reproduction) est assujettie à sa politique d'utilisation que vous pouvez consulter en ligne.

https://apropos.erudit.org/fr/usagers/politique-dutilisation/ 


\section{The effect of social and environmental disclosure on companies' market value}

\section{L'effet de la divulgation sociale et environnementale sur la valeur de marché des entreprises}

\section{El efecto de divulgación social y ambiental en el valor de mercado de las empresas}

\author{
JOCELYN HUSSER \\ Institut d'Administration des Entreprises (IAE) \\ Université de Bordeaux
}

\author{
FRÉDÉRIQUE EVRAERT-BARDINET \\ Institut d'Administration des Entreprises (IAE) \\ Université de Bordeaux
}

\section{Abstract}

The research looks at the relationship between market value, accounting fundamentals and companies' Corporate Social Responsibility (CSR) and Sustainable Development (SD) disclosures for the years 2007-2008. This article uses social and environmental scores derived from a structural analysis chart based on $120 \mathrm{com}$ panies' reports. The results show that investors measure a company's short-term performance using information about the quality of the company's environmental management. At the same time, a company's social disclosure concerning the quality of employee management influences short and long-term performance.

Key Words: Score of Environmental Disclosure, Score of Social Disclosure, Financial Performance, Market Value, Sustainable Development

\begin{abstract}
RÉSUMÉ
La recherche étudie la relation entre la valeur de marché, la valeur comptable et les informations relatives à la responsabilité sociale des entreprises (RSE) et au développement durable (DD) pour les années 2007-2008. Cet article mobilise des scores de divulgation sociale et environnementale provenant d'une grille d'analyse structurale basée sur les rapports de 120 entreprises. Les résultats montrent que les investisseurs mesurent la performance à court terme d'une entreprise en utilisant des informations sur la qualité de la gestion environnementale de l'entreprise. Dans le même temps, la communication sociale de l'entreprise concernant la qualité de la gestion du personnel influence sa performance à court terme et à long terme.

Mots clés: Score de la divulgation de l'environnement, Score de divulgation sociale, performance financière, valeur de marché, développement durable
\end{abstract}

\begin{abstract}
Resumen
El estudio analiza la relación entre el valor de mercado, el valor contable y la información sobre la responsabilidad social empresarial (RSE) y desarrollo sostenible (SD) para los años 2007-2008. En este artículo se moviliza decenas de divulgación social y ambiental de una grilla de análisis estructural basado en informes procedentes de 120 empresas. Los resultados muestran que los inversores miden el rendimiento a corto plazo de una empresa utilizando información sobre la calidad de la gestión ambiental de la empresa. Al mismo tiempo, la comunicación social del personal de gestión de calidad de la empresa afecta a su rendimiento en el corto plazo y largo plazo.

Palabras claves: puntuación de divulgación medioambiental, puntuación de divulgación social, rendimiento financiero, valor de mercado, desarrollo sostenible
\end{abstract}

$\mathrm{F}$ rance has a long tradition of social issues and conflicts that led its Parliament to pass laws and mandatory disclosure by business companies early on. A law on New Economic Regulations (NER ${ }^{1}$ ) that requires listed companies to account for the social and environment consequences of their activity came into force ten years ago. Alongside their annual reports these companies integrate a list of defined indicators which includes a number of accounting and financial items. These indicators can be classified into four main axes (Mauléon and Silva, 2009): (1) general objectives of the Corporate Social Responsibility (CSR); (2) social information (organization of working time, gender); (3) societal information (contribution to socio-economic planning, links with Non-Governmental Organizations (NGOs) and local authorities); (4) environmental information (water consumption, raw materials and energy, impact on biodiversity). While this law did represent a constraint for publicly-listed companies, the level of disclosure in those areas started low but grew significantly after 2007 in France with significant increase of voluntary disclosure in Corporate Social Responsibility (CSR) and Sustainable Development (SD) information. This increase in disclosure of environmental and social information exemplifies the interest companies have in improving their communication management and 
leads one to question their objective and ask the following questions: What benefits including financial gains do the companies expect to obtain from publishing non-financial information? What effect does combining social and environmental information have on company's market value?

The main goal of this research is to evaluate the financial impact of social and environmental communication on the financial performance of companies listed on the stock market (Nyse Euronext SBF 120 Index). CSR and SD reports include both environmental and social information in the same document. They provide investors with two different kinds of non-financial information to help them evaluate their impact on the financial performance of companies.

Founded upon the theory of information costs, the empirical study examines information disclosure in terms of sustainable development and social responsibility (published in 2007) and its financial impact on French Stock Market (SBF) 120 companies' performance (published in 2008). The analysis of the reports' content was done using an analysis chart suggested by Cormier and Magnan (2007) for the environmental aspect. A second analysis chart was used to evaluate the social aspects of the reports. It was based upon Richardson and Welker's research (2001) and the work of practitioners (Novethic, 2009). This methodology makes it possible to measure the level as well as the quality of social and environmental disclosure and their effect on company market value. Then regression analysis based on the modified Ohlson model (1985) and the "Market to Book" model was completed to check any relationship between CSR and SD data with company value creation. The originality of the research lies in the fact that, as far as the authors are aware, this is the first study to explore the joint effect of social and environmental disclosure on firms' market value.

The article is organized as follows. Section 1 addresses the conceptual issue in the context of existing literature and presents the authors' main hypothesis. Section 2 relates to the construct of the study with regards to sample, score building, variables, descriptive statistics and correlation analysis. Section 3 presents and discusses the results of regression and confirmatory components analysis.

\section{Literature study and hypothesis}

According to Wolfe and Putler (2002) and Botosan (2006), various stakeholders such as employees, customers, and also governments and lobbyists are becoming increasingly concerned about the quality and the involvement of companies in relation to their environment. They revive the initial research of Freeman and Reed (1983) and later Freeman alone (1984) which puts forth the notion that together, all of a company's partners are a source of value creation. Thus, the connection between financial performance and the disclosure of company information is in line with the idea that directors need to open up their executive governance to the stakeholders in order to explain, inform, or justify their results and to improve their financial performance.

\section{NON-FINANCIAL INFORMATION DISCLOSURE AND FINANCIAL PERFORMANCE}

Many theoretical frameworks attempt to explain the disclosure of social and environmental information and its connection to company's financial performance. The stakeholders theory considers the agency relationship broadened, in addition to the legitimacy theory and the information costs theory. The first current of thought envisions a broadened agency relationship between the company and its stakeholders, whether they can be direct or indirect as Freeman and Reed (1983) and Kochan and Rubinstein (2000) imagined them. Information disclosure is a company's response to stakeholders' demands (Patten, 2002). A response that is well-suited to expectations will improve financial performance. If companies are sensitive to the social and environmental issues, they will focus on stakeholders' "direct" or "contractual" interests, according to Andre and alii's study (2011). Thus, there is a connection between financial performance, stakeholders' targeted disclosure of information and the main subjects of the reports. All these studies consider that social and environmental reporting offers an opportunity to present corporate accounts from the standpoint of a broader agency relationship between the firm and its stakeholders.

The second current of thought looks at the legitimacy process. A company's communication is similar to a wellformed response to public opinion pressures and more precisely, to pressures from NGOs and institutions. Many studies (Wiseman, 1982; Ball and alii, 2000; Cormier and Magnan, 1999 and 2003; Husser and alii, 2012) have shown that the quantity of environmental information disclosed by companies listed on the stock exchange depends on the legal framework imposed by the Government, the company's sector as well as the degree to which they are exposed to environmental risks and, more importantly, to pollution. The large quantity of information disclosed ultimately attempts to improve the financial performance of the companies (Cormier and Magnan, 2007; Aerts and alii, 2008). Some researchers have also found that the link with a particularly sensitive sector of activity triggers a significantly higher level of environmental information dissemination (Wiseman, 1982). Moreover, in regard to the social aspect, many researchers (Guthrie and Parker, 1989; Orlitzky and alii, 2003; Dejean and Oxibar, 2007; Cormier and alii, 2011) have shown connections between society's expectations, social information disclosure, social reputation and financial performance. These studies highlight the importance of the stakeholders' actions (Clarkson, 1995). They also underline the social or environmental commitment of companies in response to demands from the external environment.

The third current of thought - the theory of information costs - helps companies make decisions about information disclosure while taking into consideration cost-advantages (Verrechia, 2001). Investors assess a firm's financial performance using regulated and non-regulated disclosure. 
For Cormier and Magnan (2003, 2007), there is a true communication strategy, which results from a compromise between the economic benefits of disclosure, the associated risks arising from stakeholder pressures and regulatory constraints. The value relevance of such non-financial disclosure is consistent with companies often revealing much more about their social and environmental activities than is required by law. Plumlee and alii (2010) link voluntary communication on environmental issues to a company's performance. Based upon a study performed on a small sample of Americans, they identified positive links between environmental disclosure, the evaluation of expected cash flows and the evaluation of the company. Additionally, Orlitzky and alii (2003) established similar connections with the financial performance, but within a context of social disclosure. More recently, Cormier, Ledoux and Magnan (2011) investigated whether social disclosure and environmental disclosure have a substituting or a complementing effect in reducing information asymmetry between managers and stock market participants. The relation between the costs and benefits to be derived from disclosure as well as the resulting balance in information asymmetry have also been the object of several extensive studies (Verrecchia, 2001; Richardson and Welker, 2001). Voluntary disclosure reduces the information asymmetry among investors. Hence investors trading shares of firms that provide extensive disclosure can be relatively confident that any transaction occurs at a fair price, thus leading to increased liquidity in these firms' shares. From an empirical perspective, there is widespread evidence that is consistent with the proposition that enhanced voluntary disclosure is positive, both in terms of enhancing firm value and stock market liquidity (Chen et al, 2007).

As a result, in addition to prior research, this paper investigates the aggregate and separate effects of CSR and $\mathrm{SD}$ disclosures on market value (H1) and market to book value $(\mathrm{H} 2)$.

Functionally speaking, the communication effort is estimated using a global disclosure score (environmental and social score). The resulting two first hypotheses are:

(H1.A) For listed companies, the relationship between the global disclosure score for CSR and SD and their market value is positive.

(H2.A) For listed companies, the relationship between the global disclosure score for CSR and SD and their market to book value is positive.

Such a dichotomy leads one to consider reviewing the literature from first the point of view of environmental disclosure and only then from a social disclosure point of view in order to formulate hypotheses related to each of those aspects.

\section{EFFECT OF ENVIRONMENTAL INFORMATION DISCLOSURE}

The study of the influence of environmental disclosure on companies' financial performance falls within the scope of the information cost approach insofar as the expected future economic advantages are reliant upon voluntarily published information (Scott, 1994; Dejean and Martinez, 2009a). A firm's perceived negligence or irresponsible environmental behavior can lead to 'regulatory' interventions on the part of the stockholders, a long-term negative reputation in the eyes of the customers and the suppliers, and could ultimately result in the firm being less attractive to future employment candidates. These types of implicit costs affect the stock value of companies. Thus, improving environmental information (risks incurred and steps put into place) allows investors to better understand the risks and to reduce the asymmetry of the costs of information.

The quality of environmental information has a double positive effect: it increases the investors' degree of certitude regarding their return on financial investments as well as the degree of the directors' credibility.

Dejean and Martinez (2009b) use the same theoretical framework when looking at the decreased cost of capital in Europe, using a synthetic score in terms of environmental disclosure. We would thus test separately an analytical score of environmental disclosure and its effect on market value followed by the same test on market to book value. In this way, we can form the following two sub-hypotheses:

(H1.B): For listed companies, the relationship between the environmental disclosure score and their market value is positive.

(H2.B): For listed companies, the relationship between the environmental disclosure score and their market to book value is positive.

\section{EFFECT OF SOCIAL INFORMATION DISCLOSURE}

The research done on the effect that social information disclosure has on companies' financial performance leads to more contrasting conclusions. If one looks at the work of Maignan and Ralston (2002) and Maignan and Ferrell (2003), social communication types differ greatly from one continent to another. If the European context - notably German and French - allows for one to flaunt high social performance scores, it can, on the other hand, be less acceptable in the United States to proclaim oneself as being socially responsible with only mediocre financial results. Moreover, the specificity of each European country was highlighted in this same work. According to Allouche and alii (2004), Europe is especially accepting of social and economic solidarity, of the citizenship of the company, and of the coexistence of different organizational, financial 
and social goals. Therefore, stakeholders often compare social performance to financial performance (Caroll, 1979). Within the framework of this research and given the sample used in it, the European context certainly prevails and the notion of a strong influence of social information disclosure on financial performance dominates.

The first studies on social and financial performance disclosure (Roman and alii, 1999; Margolis and Walsh, 2002 and 2007) reveal a probable influence, which is contrasted and attenuated by the size and sectorial effects. However, determining social disclosure scores that are supported by human factors which are theoretically and practically founded still needs to be developed. A second series of articles (Botosan and Plumlee, 2002; Richardson and Welker, 2008; Dhaliwal and alii, 2011) explores the connections between social performance, social disclosure and capital cost. Several models, including those based on updated dividends, the capital asset pricing model (CAPM) or the Ohlson model (1995) converge to form the same conclusion: that improving social information disclosure leads to a decrease in capital cost (Richardson and Welker, 2001; Botosan and Plumlee, 2002). However, the surfeit of information can confuse investors, producing a moderating effect on the decrease of cost of capital.

Unfortunately, very few current studies have explored the link between social information disclosure and financial performance. Criteria such as stock market values and Market-to-Book ratio have not been shown recently to be clearly and directly related to social information disclosure. Two additional hypotheses need then to be tested.

(H1.C): For listed companies, the relationship between the social disclosure score and their market value is positive.

(H2.C): For listed companies, the relationship between the social disclosure score and their market to book value is positive.

\section{Methodology}

To estimate the effect that information disclosure has on performance, companies listed on the French stock market (SBF 120 Index) were studied. Two models were used to test these variables in order to explain market values. This section introduces the data-collection method as well as the method used to determine the disclosure scores, the sample, the variables, and the tested models.

\section{REPORTING SCORE MEASUREMENT}

Findings show that two forms of report are used to measure corporate scores in environmental and social disclosure: reports on companies' activities and reports on Sustainable Development (SD) and Corporate Social Responsibility (CSR). The reports on SD and CSR are more numerous in 2007 than those used by Dejean and Martinez in 2006. These reports were downloaded from SBF 120 websites.

Firstly, the data collection on CSR and SD provided information for the two analytical grids presented in appendices $1 \mathrm{a}$ and $1 \mathrm{~b}$. The two grids were the result of a qualitative analysis based on a structural analysis of the contents presented in appendix 2. A structural analysis method provides the two grids (one about environmental aspect and a second one regarding social issue). Initiated by Barthes (1991) and implemented by Demazière and Dubar (1997), this approach offers the advantage of giving the researcher an analytical framework that is structured and coherent and helps to avoid three obstacles: 1) The illustrative stance that arbitrarily selects just a few excerpts from interviews for illustration purposes and leads to a loss of content. 2) The restorative attitude that reproduces contents in their entirety without any interpretation. 3) An absence of objectification, avoided due to the implementation of a procedure that is both standardized and systematic. The structural analysis was made by two researchers in order to validate the data collection.

The grid of environmental analysis, designed from the work of Cormier and Magnan (2007), generated a set of categories of information. The research done graded the 6 following themes (from 1 point meaning low to 3 points meaning high): environmental hazards, law and regulations, treatment of pollution, conservation of natural resources, site remediation, and environmental management. For each environmental theme, pieces of information are subject to a rating, according to the recommendations of Cormier and Magnan (2007). Finally, for each company, a score of environmental disclosure is obtained from the sum of the scores estimated by theme (maximum of 18 points).

The social analysis grid was designed according to work carried out by Dhaliwal and alii (2011) and that of Novethic (2009). The synthesis of the two approaches revealed 6 main themes, graded from 1 point for low to 3 points for high: Positioning of the employees in the company's strategy, sensitization actions, training actions, integration of CSR policy in Human Resource Management (HRM), and lastly employee mobilization. The same range of grades is applied ( 1 being low and 3 being high) to each social theme. Grade 3, the highest rating means that information is accurate and quantified. Finally, for each company, a score of social disclosure is obtained by adding up the scores obtained per theme (maximum of 18 points).

Secondly, the two analytical grids led to a calculation that measures a global disclosure score, obtained from the sum of the two previous scores (environmental and social; maximum of 36 points). 


\section{SAMPLe, VARIABleS MEASUREMENT AND DESCRIPTIVE STATISTICS}

The sample comprises French listed companies in NYSE Euronext SBF 120 Index, many of them operating in Europe and overseas. Accounting and financial fundamentals are extracted from Thomson Financials and Datastream databases. The research analyses a company's report on sustainable development or its activity report in order to measure the level of environmental and social disclosure. Banks, insurance companies and financial services firms are excluded in order to obtain a sample of firms that use homogeneous accounting principles. The final sample includes 103 firms for year 2008 (see appendix 3).

\section{VARIABLES MEASUREMENT}

We test the relation between market value, market to book value, accounting fundamentals and the level of social and environmental disclosure. The dependent variable is respectively the market value and the market to book value of the firm. The independent variables are successively the book value, the net income, the level of disclosure and the total assets in order to control the size effect. To assess the robustness of the results, we carry out additional analysis with two factors of contingency: the sector (polluting/nonpolluting) and the size (number of employees). All variables and their sources are described in table 1 below.

\section{Descriptive statistics}

The following tables (2 and 3) show that companies give out information regarding change management and training plans. Then, they deliver details about employee's mobilization. The positioning of employees related to firm's strategy is less widespread. The analysis of environmental content shows that the score is much higher than the one obtained from social disclosure. Moreover, the item "environmental hazards" presents the lowest mean (1.37). The research resorted to $85 \mathrm{SD}$ reports and 18 activity reports. The t-tests of means don't show any significant differences.

We observe that the firms show a wide range of size, performance and net income (table 4). The mean of the market value is around 8 billion euros, 19 billion euros for total assets, 600 million euros for net income, 8 billion euros for book value and the average number of employees amounts

\section{TABLE 1}

\section{Variable definitions}

\begin{tabular}{|c|c|c|c|}
\hline Variable & Definition and measurement & Sign & Source \\
\hline \multicolumn{4}{|c|}{ Dependent variable } \\
\hline MVEs & Market value of equity per share (fiscal year end) & & Thomson Financials/Datastream \\
\hline $\mathrm{MtB}$ & Market to book ratio & & Thomson Financials/Datastream \\
\hline \multicolumn{4}{|c|}{ Explanatory variable } \\
\hline BVS & Book value per share & + & Thomson Financials \\
\hline ROE & Earnings/book value & + & Thomson Financials \\
\hline EPS & Earnings per share & + & Thomson Financials \\
\hline SENVT & Environmental Reporting Score & + & Activity report and SD report \\
\hline SSOC & Social Reporting Score & + & Activity report and SD report \\
\hline SGLOB & $\begin{array}{l}\text { Global Reporting Score: Environmental Reporting Score } \\
+ \text { Social Reporting Score }\end{array}$ & + & Activity report and SD report \\
\hline \multicolumn{4}{|c|}{ Control variable } \\
\hline TA & Natural log of Total assets & + & Thomson Financials \\
\hline POLL & $\begin{array}{l}\text { Is a dummy variable coded } 1 \text { if the firm is polluting, } \\
0 \text { otherwise }\end{array}$ & + & Carbon Disclosure Project 2007 \\
\hline EMPL & $\begin{array}{l}\text { Is a dummy variable coded } 1 \text { if the firm employee is higher } \\
\text { than the median, } 0 \text { otherwise }\end{array}$ & + & Thomson financials and activity report \\
\hline
\end{tabular}




\section{TABLE 2}

\section{Environmental reporting score by items - Descriptive statistics}

\begin{tabular}{l|c|c|c}
\hline \multicolumn{1}{c|}{$\begin{array}{c}\text { Environmental reporting } \\
\text { score by items }\end{array}$} & $\mathbf{N}$ & Mean & Std. dev. \\
\hline Environmental hazards & 103 & 1.37 & 0.542 \\
\hline Laws and regulations & 103 & 1.84 & 0.5 \\
\hline Pollution abatement & 103 & 1.79 & 0.517 \\
\hline $\begin{array}{l}\text { Conservation of natural } \\
\text { resources }\end{array}$ & 103 & 1.9 & 0.569 \\
\hline $\begin{array}{l}\text { Land remediation and } \\
\text { contamination }\end{array}$ & 103 & 1.91 & 0.658 \\
\hline $\begin{array}{l}\text { Environmental Management } \\
\text { Environmental reporting score }\end{array}$ & 103 & 2 & 0.686 \\
\hline \hline
\end{tabular}

TABLE 3

\section{Social reporting score by items - Descriptive statistics}

\begin{tabular}{l|c|c|c}
\hline \multicolumn{1}{c|}{$\begin{array}{c}\text { Social reporting score } \\
\text { by items }\end{array}$} & $\mathbf{N}$ & Mean & Std. dev. \\
\hline $\begin{array}{l}\text { Positioning of employees } \\
\text { related to the business strategy }\end{array}$ & 103 & 1.5 & 0.502 \\
\hline $\begin{array}{l}\text { Awareness actions - } \\
\text { sensitization }\end{array}$ & 103 & 1.99 & 0.383 \\
\hline $\begin{array}{l}\text { Training and education efforts } \\
\text { Management efforts targeting } \\
\text { a fixed change in CSR politics: } \\
\text { real motivation in HRM }\end{array}$ & 103 & 2.16 & 0.459 \\
\hline $\begin{array}{l}\text { CSR integrated into HRM: } \\
\text { recruitment, evaluation, } \\
\text { remuneration }\end{array}$ & 103 & 2.08 & 0.413 \\
\hline $\begin{array}{l}\text { Realization of employee } \\
\text { mobilization }\end{array}$ & 103 & 2.07 & 0.598 \\
\hline \begin{tabular}{l} 
Social reporting score \\
\hline \hline
\end{tabular} & 103 & 12 & 1.868 \\
\hline
\end{tabular}

to 56,000 . The means of environmental and social disclosure are respectively 10.8 and 12 for a maximum of 18 , the mean of the global score is 22.8 (maximum 36). Over the period, the market value per share is around 26.8 and 1.53 for the "Market to book ratio". Firms are profitable, with a mean ROE of $8 \%$, with a wide standard deviation.

\section{Correlation analysis}

Table 5 shows Pearson cross correlation between all variables used in the study. As expected, the market value is positively related with accounting fundamentals, net income, book value, total assets and environmental and global reporting. However, the market value is not related to social disclosure. Pearson correlation between explanatory variables shows a positive relation between net income and book value, between environmental and global score, and between social and global score. The relation between social and environmental score is rather low.

\section{Effects of contingency}

To assess the relevance of disclosure and the results' robustness, we carry out additional analysis with two factors of contingency included in the model. We used the "Carbon disclosure project's grid" 2007 to investigate whether the sector (polluting/non-polluting) and the size (median number of employees) have a different effect on firm market value. The sector ("Carbon disclosure project 2007") should have some influence, because polluting firms are more sensitive to environmental issues. Similarly, large firms should be pushed to disclose more pieces of information about employees.

\section{VALUATION MODELS AND PRINCIPAL COMPONENTS ANALYSIS}

Two models were used to measure the effect of disclosure on financial performance: the modified Ohlson model (1995) and the market to book model. The analysis is completed by a principal components analysis method to identify the mean communication themes.

\section{Market model: model 1}

The research aims to test whether the financial market values the efforts made by the company in terms of environmental and social communication. The modified model of Ohlson (1995), called the residual earnings model, is one of the most often used models in financial accounting and in research on sustainable development (Clarkson and alii, 2004, 2008, 2010; Plumlee, 2010). Market value is equal to the sum of book equity plus the present value of future abnormal returns.

\section{Model 1: Regression equation $n^{\circ} 1$}

MVESi, $t=a_{0}+a_{1} B V S i, t+a_{2} E P S i, t+a_{3} \operatorname{SCORE}_{i, t-1}$ $+a_{4}$ LTAi,t + ei,t.

MVESi,t: Market value of equity per share for firm $i$, year $t$.

BVSit: Book value per share for firm $i$ year $t$.

EPSit: Earnings per share for firm $i$ year $t$.

SCOREit-1: Reporting score for firm $i$ year $t-1$ (respectively global score, environmental score and social score).

LTAit: Natural $\log$ of total assets for firm $i$, year $t$. 


\section{TABLE 4}

\section{Descriptive statistics (sample)}

\begin{tabular}{l|c|c|c|c|c}
\hline $\begin{array}{c}\text { Variable }(\mathbf{M} €) \\
\mathbf{N = 1 0 3}\end{array}$ & Mean & Median & Std. dev. & Min. & Max. \\
\hline MVE & 7,951 & 2,227 & 15,997 & 20 & 92,287 \\
\hline BV & 5,515 & 1,590 & 10,091 & $-2,194$ & 57,747 \\
\hline NI & 599 & 163 & 1,601 & $-5,215$ & 10,590 \\
\hline TA & 18,902 & 5,227 & 32,840 & 151 & 200,288 \\
\hline
\end{tabular}

Score and ratios

\begin{tabular}{l|c|c|c|c|c}
\hline SSOC & 12 & 12 & 1.86 & 8 & 17 \\
\hline SENVT & 10.8 & 11 & 2.32 & 6 & 17 \\
\hline SGLOB & 22.8 & 23 & 3.31 & 15 & 33 \\
\hline EMPL & 56,080 & 17,978 & 82,160 & 49 & 479,072 \\
\hline MVEs & 26.8 & 20.4 & 21.25 & 0.16 & 138 \\
\hline BVS & 21.3 & 17.4 & 19.11 & -7.81 & 103.03 \\
\hline EPS & 1.46 & 1.8 & 8.50 & -72.8 & 26.8 \\
\hline MTB & 1.53 & 1.2 & 1.59 & -1.8 & 11.4 \\
\hline ROE & 0.08 & 0.11 & 0.29 & -2.02 & 1.01 \\
\hline \hline
\end{tabular}

MVE: market value of equity; BV: book value; NI: net income; TA: total assets; SSOC: social reporting score; SENVT: environmental reporting score; SGLOB: total reporting score; EMPL: employee; MVES: market value of equity per share; BVS: book value per share; EPS: earnings per share; MTB: market to book ratio; ROE: return on equity.

TABLE 5

Pearson correlation matrix between market value, accounting measures and reporting score

\begin{tabular}{|c|c|c|c|c|c|c|c|}
\hline & MVES & BVS & EPS & SSOC & SENVT & SGLOB & LNTA \\
\hline MVES & 1 & $0.588 *$ & $0.381 *$ & 0.061 & $0.244 * *$ & $0.206 * *$ & $0.197 * *$ \\
\hline BVS & & 1 & 0.398* & $-0.201 * *$ & 0.107 & -0.038 & $0.252 *$ \\
\hline EPS & & & 1 & -0.041 & 0.056 & $0.016 * * *$ & 0.062 \\
\hline SSOC & & & & 1 & $0.244 * *$ & 0.734* & -0.015 \\
\hline SENVT & & & & & 1 & 0.838* & $0.376^{*}$ \\
\hline SGLOB & & & & & & 1 & $0.254 *$ \\
\hline LNTA & & & & & & & 1 \\
\hline
\end{tabular}

${ }^{*}$ significant at the $1 \%$ level; ${ }^{* *}$ significant at the $5 \%$ level; ${ }^{* * *}$ significant at the $10 \%$ level.

MVES: Market value of equity per share; BVS: Book value per share; EPS: Earnings per share; SSOC: Social reporting score; SENVT: Environmental reporting score; SGLOB:Global reporting score; TA: Natural log of total assets. 


\section{Market to book model: model 2}

The explanation of the difference between market value of equity and book value of equity is a recurring issue in financial accounting research that gave rise to many interpretations. The book value depends on the equity invested and market capitalization fluctuates according to orders to buy or to sell. For some scholars, it is a representative standard of errors of securities' valuations and reveals the existence of a risk premium and errors of selection in the samples used (Fama and French, 1995, Frankel et lee, 1998, Cazavan-Jeny, 2004). For other scholars like Lev and Sougiannis (1996) and Amir and Lev (1996), it highlights other intangible or physical assets not valued by the accounting model but valued by investors. The market to book model was used by Cormier et Magnan (2007) in the context of sustainable development.

\section{Model 2: Regression equation $n^{\circ} 2$}

\section{MtB i, $t=a 0+a 1$ 1/BV i, $t+a 2 \operatorname{ROE~} i, t+a 3$ SCORE i,t-1 + a4 LTA i, t + ei,t.}

MtBit: Market to book ratio for firm $i$, year $t$.

1/BVit: Book value of equity for firm $i$, year $t$;

ROEit: Return on equity for firm $i$, year $t$.

SCOREit-1: Reporting score for firm $i$ year $t-1$ (respectively global score, environmental score and social score)

LTAit: Natural log of total assets for firm $i$, year $t$.

\section{Principal components analysis}

A principal components analysis was undertaken across the two disclosure scores. It aims to seek both scores: the main disclosure axis that is main communication patterns towards stakeholders and the present context towards stockholders. Disclosure scores designed by previous studies (Cormier and Magnan, 2007 and 2008; Dejean and Martinez, 2009a, 2009 b) were synthetic scores and did not envision any hierarchical classification in order to explain the components obtained. The main components are analyzed through the research of key variables. These are determined by a correlation and contribution matrix obtained from the first axis.

\section{Results and discussion}

This part aims to present the results of the Ohlson model (model 1), the model "Market to book" (model 2), the principal components analysis and those incorporating the effects of contingency.

\section{LEVEL OF REPORTING AND MARKET VALUE: MODEL 1 RESULTS}

The model is tested separately for each variable of disclosure: the global disclosure score $\left(\mathrm{SGLOB}_{\mathrm{i}, \mathrm{t}-1}\right)$, the environmental score $\left(\operatorname{SENVT}_{\mathrm{i}, \mathrm{t}-1}\right)$ and the social score $\left(\mathrm{SSOC}_{\mathrm{i}, \mathrm{t}-1}\right)$.

\section{Regression equations Model 1:}

Equation 1a: MVESi, $\mathrm{t}=\mathrm{a}_{0}+\mathrm{a}_{1}$ BVSi, $\mathrm{t}+\mathrm{a}_{2}$ EPSi, $\mathrm{t}$ $+\mathrm{a}_{3} \mathrm{SGLOB}_{\mathrm{i}, \mathrm{t}-1}+\mathrm{a}_{4}$ LTAi,t + ei,t.

Equation 1b: MVESi, $\mathrm{t}=\mathrm{a}_{0}+\mathrm{a}_{1}$ BVSi, $\mathrm{t}+\mathrm{a}_{2}$ EPS, it $+a_{3}$ SENVT $_{i, t-1}+a_{4}$ LTAi,t + ei,t.

Equation 1c: MVESi, $\mathrm{t}=\mathrm{a}_{0}+\mathrm{a}_{1}$ BVSi, $\mathrm{t}+\mathrm{a}_{2}$ EPSi, $\mathrm{t}$ $+\mathrm{a}_{3} \mathrm{SSOC}_{\mathrm{i}, \mathrm{t}-1}+\mathrm{a}_{4}$ LTAi,t + ei,t.

The results show a satisfactory quality of fit with market models. The $\mathrm{R}^{2}$ is around $40 \%$ and the models are significant (table 6).

The market value of the companies is positively and significantly associated with book value, the environmental score, the social score and the global score and less with earnings per share. The global score shows the best fit of this model (42.2\%). The global score of disclosure is a relevant variable to explain market value.

\section{LEVEL OF REPORTING AND MARKET TO BOOK VALUE: MODEL 2 RESULTS}

This part is dedicated to examine the association between the "market to book value", the global disclosure score $\left(\mathrm{SGLOB}_{\mathrm{i}, \mathrm{t}-1}\right)$, the environmental disclosure score $\left(\mathrm{SENVT}_{\mathrm{i}, \mathrm{t}-1}\right)$ and the social disclosure score $\left(\mathrm{SSOC}_{\mathrm{i}, \mathrm{t}-1}\right)$.

\section{Regression equations model 2}

MtB it $=\mathrm{a}_{0}+\mathrm{a}_{1}$ 1/BVit $+\mathrm{a}_{2}$ ROEit $+\mathrm{a}_{3}$ SGLOB $_{\mathrm{i}, \mathrm{t}-1}$ $+\mathrm{a}_{4}$ LTAit + ei,t (equation 2a)

MtB it $=a_{0}+a_{1} 1 /$ BVit $+a_{2}$ ROEit $+a_{3}$ SSENVT $_{i, t-1}$ $+a_{4}$ LTAit + ei,t (equation 2b)

MtB it $=a_{0}+a_{1} 1 /$ BVit $+a_{2}$ ROEit $+a_{3}$ SSOC $_{i, t-1}$ $+\mathrm{a}_{4}$ LTAit + ei,t (equation $2 \mathrm{c}$ )

Table 7 reports our findings about equations $2 \mathrm{a}, 2 \mathrm{~b}$ and 2c. All the regressions are statistically significant, adjusted $\mathrm{R}$-square is around $30 \%$. The book value and the ROE are positively and significantly related to the "market-to-book" ratio. The coefficients of social and global disclosure score are positive and also significant. By contrast, the coefficient of environmental score is not significant.

\section{Principal Components anAlysis Results}

A principal components analysis was undertaken on the variables linked to "environmental score" and on variables related to "social score", that is to say six variables for each score. The results for the score "environmental" show that the score for axis 1 alone accounts for $37.78 \%$ of the total variance and axis 2 contributes to $32.30 \%$ of the total variance after varimax rotation. The principal plan including the two axes explains $70.08 \%$ of the total variance. The results obtained in terms of correlation of and contribution to the 6 variables on both axes are presented in table 8 . 
TABLE 6

Stock price model results (sample)

MODEL 1

MVEs: Dependent variable

Coefficient estimations (p-value)

\begin{tabular}{l|c|c|c}
\hline \multicolumn{1}{c|}{ Nobs: 103 } & $\begin{array}{c}\text { Equation 1a } \\
\text { (Global score) }\end{array}$ & $\begin{array}{c}\text { Equation 1b } \\
\text { (Environmental score) }\end{array}$ & $\begin{array}{c}\text { Equation 1c } \\
\text { (Social score) }\end{array}$ \\
\hline Const. & $-18.21(0.310)$ & $-1.191(0.909)$ & $-21.876(0.269)$ \\
BVS & $\mathbf{0 . 5 9 2}(\mathbf{0 . 0 0 0})$ & $\mathbf{0 . 5 5 9 * ( \mathbf { 0 . 0 0 0 } )}$ & $\mathbf{0 . 6 0 5 * ( \mathbf { 0 . 0 0 0 } )}$ \\
EPS & $\mathbf{0 . 4 1 * * * ( \mathbf { 0 . 0 5 1 } )}$ & $\mathbf{0 . 4 2 * * ( \mathbf { 0 . 0 4 7 } )}$ & $\mathbf{0 . 4 2 1} * *(\mathbf{0 . 0 5 0})$ \\
SGLOB & $\mathbf{1 . 4 3 * ( \mathbf { 0 . 0 0 6 } )}$ & $\mathbf{1 . 6 9 * *}(\mathbf{0 . 0 3 1})$ & \\
SENVT & & & $\mathbf{2 . 0 2 8 * * ( \mathbf { 0 . 0 2 7 } )}$ \\
SSOC & & -0.133 & $0.698(0.521)$ \\
LTA & $-0.062(0.955)$ & $40.40 \%$ & $40.60 \%$ \\
\hline $\mathrm{R}^{2}$ & $42.20 \%$ & $38 \%$ & $38.10 \%$ \\
$\mathrm{R}^{2}$ adj & $39.80 \%$ & $16.63(0.000)$ & $16.71(0.000)$ \\
Fisher (p-value) & $17.86(0.000)$ & 2.062 & 2.106 \\
Durbin-Watson & 2.084 & & \\
\hline \hline
\end{tabular}

${ }^{*}$ significant at the $1 \%$ level; ${ }^{* *}$ significant at the $5 \%$ level; ${ }^{* * *}$ significant at the $10 \%$ level.

MVES: Market value of equity per share; BVS: Book value per share; EPS: Earnings per share; SENVT: Environmental reporting score; SSOC: Social reporting score; SGLOB: Global reporting score; LTA: Natural log of total assets.

TABLE 7

Market to book model results (sample)

MODEL 2

MTB: Dependent Variable

Coefficient estimations (p-value)

\begin{tabular}{|c|c|c|c|}
\hline $\mathrm{N}: \mathbf{1 0 3}$ & $\begin{array}{c}\text { Equation 2a } \\
\text { (Global score) }\end{array}$ & $\begin{array}{c}\text { Equation 2b } \\
\text { (Environmental score) }\end{array}$ & $\begin{array}{c}\text { Equation 2c } \\
\text { (Social score) }\end{array}$ \\
\hline Cons & $-0.858(0.621)$ & $0.212(0.899)$ & $-0.858(0.621)$ \\
\hline $1 / \mathrm{BV}$ & $155650.3 * *(0.035)$ & $1486622.4 * *(0.049)$ & $155650.3 * *(0.035)$ \\
\hline ROE & $2.527 *(0.000)$ & $2.531 *(0.000)$ & $2.527 *(0.000)$ \\
\hline SGLOB & $0.079 * * *(0.057)$ & & \\
\hline SENVT & & $0.080(0.207)$ & \\
\hline SSOC & & & $0.079 * * *(0.057)$ \\
\hline LTA & $0.013(0.903)$ & $0.006(0.960)$ & $0.013(0.903)$ \\
\hline $\mathrm{R}^{2}$ & $33.10 \%$ & $31.70 \%$ & $33.10 \%$ \\
\hline $\mathrm{R}^{2}$ adj & $30.40 \%$ & $28.90 \%$ & $30.40 \%$ \\
\hline Fisher (p-value) & $12.146 *(0.000)$ & $11.385(0.000)^{*}$ & $12.146 *(0.000)$ \\
\hline Durbin-Watson & 2.1 & 2.088 & 2.1 \\
\hline
\end{tabular}

${ }^{*}$ significant at the $1 \%$ level; ${ }^{* *}$ significant at the $5 \%$ level; ${ }^{* * *}$ significant at the $10 \%$ level.

MTB: Price to book ratio; BV: Book value of equity; ROE: return on equity; SGLOB: Global reporting score; SENVT: Environmental reporting score; SSOC: Social reporting score; LTA: Natural log of total assets. 


\section{TABLE 8}

Correlations and percentage of variance for environmental reporting score

\begin{tabular}{l|c|c|c|c}
\hline \multicolumn{1}{c|}{ Environmental Reporting Score } & \multicolumn{2}{c|}{ Axis 1 (37.78 \% of total variance) } & \multicolumn{2}{c}{ Axis 2 (32.30 \% of total variance) } \\
\hline \multicolumn{1}{c|}{ Variables } & correlation & $\mathbf{\%}$ & correlation & \% \\
\hline Environmental hazards & 0.445 & $7.35 \%$ & $\mathbf{0 . 4 1}$ & $\mathbf{2 9 . 7 \%}(*)$ \\
\hline Laws and regulations & 0.565 & $11.85 \%$ & $\mathbf{0 . 2 3}$ & $\mathbf{2 7 . 2} \%(*)$ \\
\hline Pollution treatment & $\mathbf{0 . 7 4 4}$ & $\mathbf{2 0 . 5 5 \% ( * )}$ & 0.47 & $6.43 \%$ \\
\hline Conservation of natural resources & $\mathbf{0 . 7 5 9}$ & $\mathbf{2 1 . 3 8 \% ( * )}$ & 0.18 & $14.82 \%$ \\
\hline Land remediation and contamination & $\mathbf{0 . 7 1 6}$ & $\mathbf{1 9 . 0 7 \% ( * )}$ & 0.17 & $13.13 \%$ \\
\hline Environmental Management & $\mathbf{0 . 7 3}$ & $\mathbf{1 9 . 7 9 \% ( * )}$ & 0.09 & $8.65 \%$ \\
\hline \hline
\end{tabular}

$\left.{ }^{\star}\right)$ Contribution $>$ of the mean $(15 \%)$

On axis 1 , four variables contribute significantly and are in order of importance: pollution treatment, natural resources consumption, site renovation (land remediation and contamination), environmental management. This first axis corresponds to actions i.e. a specific mode of management being "environment friendly". It is an "actual short term management" implemented by precise actions that get a short term result. On axis 2, only two variables contribute significantly: environmental risks, law and regulations. This axis reveals another behavior: a disclosure oriented to the firm's compliance to laws and regulations: "legal compliance".
The results obtained from the "social" score show axis 1 explains $42 \%$ of the total variance (TV) and axis 2 contributes to $23.7 \%$ of TV. The main plan obtained from these two axes explains $65.7 \%$ of the total variance. From table 9 it is possible to observe that the "social" score is less explained than the environmental one. The disclosure of social aspects of sustainability reports appears to be more diluted, more heterogeneous and less structured than the disclosure regarding environmental issues.

On axis 1, four variables contribute significantly: CSR management efforts, training, mobilization, awareness. This axis expresses the actions and social means implemented by

\section{TABLE 9}

Correlations and percentage of variance for social reporting score

\begin{tabular}{l|c|c|c|c}
\hline \multicolumn{1}{c|}{ Social Reporting Score } & \multicolumn{2}{c|}{ Axis 1 (42 \% of total variance) } & \multicolumn{2}{c}{ Axis 2 (23.7 \% of total variance) } \\
\hline \multicolumn{1}{c|}{ Variables } & correlation & $\mathbf{\%}$ & correlation & \% \\
\hline $\begin{array}{l}\text { Positioning of employees related } \\
\text { to the business strategy }\end{array}$ & 0.47 & $8.80 \%$ & $\mathbf{0 . 7 2}$ & $\mathbf{4 7 . 6 \%}(*)$ \\
\hline Awareness actions - sensitization & $\mathbf{0 . 6 6}$ & $\mathbf{1 7 . 9 \%}(*)$ & -0.23 & $4.80 \%$ \\
\hline Training and education efforts & $\mathbf{0 . 6 8}$ & $\mathbf{1 9 . 3 \%}(*)$ & $\mathbf{0 . 4 8}$ & $\mathbf{2 1 \%}(*)$ \\
\hline $\begin{array}{l}\text { Management efforts targeting a fixed change } \\
\text { in CSR politics: real motivation in HRM }\end{array}$ & $\mathbf{0 . 7 6}$ & $\mathbf{2 3 . 9 \%}(*)$ & -0.14 & $1.90 \%$ \\
\hline $\begin{array}{l}\text { CSR integrated into HRM: recruitment, } \\
\text { evaluation, remuneration }\end{array}$ & 0.51 & $10.50 \%$ & $\mathbf{0 . 4 2}$ & $\mathbf{1 6 . 2 \%}(*)$ \\
\hline \begin{tabular}{l} 
Realization of employee mobilization \\
\hline \hline
\end{tabular} & $\mathbf{0 . 6 8}$ & $\mathbf{1 9 . 3 \%}(*)$ & -0.28 & $7.30 \%$ \\
\hline
\end{tabular}

$\left.{ }^{*}\right)$ Contribution $>$ of the mean $(15 \%)$ 
the company. It refers to "social mobilization". On axis 2, three variables contribute significantly: the integrated social policy in the strategy, training and integration of CSR in HRM. This second axis expresses some results achieved by the company through "social control" exerted in the CSR area. Finally the PCA (Principal Components Analysis) identified two social factors "social mobilization" and "social control" and two environmental factors "actual environmental risks management" and "law compliance". These factors are then incorporated in the tested models.

\section{Regression equations Model 1 with PCA}

Equation 1d: MVESi, $\mathrm{t}=\mathrm{a}_{0}+\mathrm{a}_{1}$ BVSi, $\mathrm{t}+\mathrm{a}_{2}$ EPSi, $\mathrm{t}$ $+\mathrm{a}_{3}$ LTAi,t $+\mathrm{a}_{4}$ F1SOCi,t-1 + $\mathrm{a}_{5}$ F2SOCi,t-1 + ei,t.

Equation 1e: MVESi, $\mathrm{t}=\mathrm{a}_{0}+\mathrm{a}_{1}$ BVSi, $\mathrm{t}+\mathrm{a}_{2}$ EPSi, $\mathrm{t}$ $+\mathrm{a}_{3}$ LTAi, $\mathrm{t}+\mathrm{a}_{4}$ F1ENVT i,t-1 + $\mathrm{a}_{5}$ F2ENVTi,t-1 + ei,t.

By integrating the results of the principal component analysis (equations $\mathrm{d}$ and e), the factor 2 environment (legal and regulatory disclosure) is significant at the $5 \%$ level and positively associates with the company's market value.

\section{Regression equations Model 2 with PCA}

MtB i,t $=\mathrm{a}_{0}+\mathrm{a}_{1}$ 1/BVi, $\mathrm{t}+\mathrm{a}_{2}$ ROEi, $\mathrm{t}+\mathrm{a}_{3}$ LTAi, $\mathrm{t}+\mathrm{a}_{4}$ F1SOC i,t-1 + a F2SOC i,t-1 + ei,t (equation 2d)

MtB i, $\mathrm{t}=\mathrm{a}_{0}+\mathrm{a}_{1}$ 1/BVi, $\mathrm{t}+\mathrm{a}_{2}$ ROEi, $\mathrm{t}+\mathrm{a}_{3}$ LTAi, $\mathrm{t}+$ SCORE $\mathrm{a}_{4}$ F1ENVT i,t-1 + a $a_{5}$ F2ENVT i,t-1 + ei,t (equation 2e)

The "social control factor" is highly significant and improves the model quality $(\mathrm{R} 2=33.8 \%)$. Social control is positively related to the market to book ratio. These findings suggest that investors are pragmatic and action-oriented: factor 2 deals with the positioning of the employees and the human resources in the company's strategy.

\section{MODEL CONTROLLING BY SECTOR AND BY SIZE}

Two additional analyses are performed with firm sector and firm size. The results are presented for the model 1 and 2 in appendices 4, 5, 6, 7 for high polluting and low polluting firms, for smaller and larger firms.

As expected, environmental disclosure and especially "actual management of the environment" are positively

TABLE 10

Stock price model results (sample) with social and environmental components

MODEL 1

MVES: Dependent variable

\begin{tabular}{|c|c|c|}
\hline \multirow[b]{2}{*}{ Nobs: 103} & \multicolumn{2}{|c|}{ Coefficient estimations (p-value) } \\
\hline & $\begin{array}{c}\text { Equation 1d } \\
\text { (Social Components: Social mobilization } \\
\text { and social control) }\end{array}$ & $\begin{array}{c}\text { Equation 1e } \\
\text { (Environmental components: Actual management } \\
\text { of the environment, law and regulations disclosure) }\end{array}$ \\
\hline Const. & $2.136(0.899)$ & $16.343(0.363)$ \\
\hline BVS & $0.595 *(0.000)$ & $0.563 *(0.000)$ \\
\hline EPS & $0.43 * *(0.049)$ & $0.42 * *(0.048)$ \\
\hline LTA & $0.732(0.505)$ & $-0.136(0.907)$ \\
\hline F1SOC & $2.373(0.169)$ & \\
\hline F2SOC & $2.712(0.108)$ & \\
\hline F1ENVT & & $2.234(0.204)$ \\
\hline F2ENVT & & $3.524 * *(0.042)$ \\
\hline $\mathrm{R}^{2}$ & $40.30 \%$ & $40.90 \%$ \\
\hline $\mathrm{R}^{2}$ adj & $37.20 \%$ & $37.80 \%$ \\
\hline Fisher (p-value) & $13.098(0.000)$ & $13.423(0.000)$ \\
\hline Durbin-Watson & 2.081 & 2.047 \\
\hline
\end{tabular}

${ }^{*}$ significant at the $1 \%$ level; ${ }^{* *}$ significant at the $5 \%$ level; ${ }^{* *}$ significant at the $10 \%$ level.

MVES: Market value of equity per share; BVS: Book value per share; EPS: Earnings per share; LTA: Natural log of total assets; F1SOC: Social Mobilization; F2SOC: Social Control; F1ENVT: Actual management of the environment; F2ENV: Law and regulations disclosure. 


\section{TABLE 11}

\section{Market to book model results (sample) with social and environmental components}

\section{MODEL 2}

MTB: Dependent Variable

Coefficient estimations ( $\mathrm{p}$-value)

\begin{tabular}{|c|c|c|}
\hline $\mathrm{N}=103$ & $\begin{array}{c}\text { Equation 2d } \\
\text { (Social Components: Social mobilization } \\
\text { and Social control) }\end{array}$ & $\begin{array}{c}\text { Equation 2e } \\
\text { (Environmental components: Actual management } \\
\text { of the environment, law and regulations disclosure) }\end{array}$ \\
\hline Cons & $-0.217(0.896)$ & $0.912(0.618)$ \\
\hline $1 / \mathrm{BV}$ & $181166.2 * *(0.014)$ & $160289.9 * *(0.039)$ \\
\hline ROE & $2.517 *(0.000)$ & $2.498^{*}(0.000)$ \\
\hline LTA & $0.086(0.407)$ & $0.015(0.894)$ \\
\hline F1SOC & $0.089(0.499)$ & \\
\hline F2 SOC & $0.271 * *(0.044)$ & \\
\hline F1 ENVT & & $0.091(0.627)$ \\
\hline F2 ENVT & & $0.187(0.177)$ \\
\hline $\mathrm{R}^{2}$ & $33.80 \%$ & $32.10 \%$ \\
\hline $\mathrm{R}^{2}$ adj & $30.30 \%$ & $28.60 \%$ \\
\hline Fisher (p-value) & $9.886 *(0.000)$ & $9.178 *(0.000)$ \\
\hline Durbin-Watson & 2.058 & 2.073 \\
\hline
\end{tabular}

${ }^{*}$ significant at the $1 \%$ level; ${ }^{* *}$ significant at the $5 \%$ level; ${ }^{* *}$ significant at the $10 \%$ level.

MTB: Price to book ratio; BV: Book value of equity; ROE: return on equity; LTA: Natural log of total assets; F1SOC: Social Mobilization; F2SOC: Social Piloting; F1ENVT: Actual management of the environment; F2ENV: Law and regulations disclosure.

associated with market value for high polluting firm and improve the quality of the model (R-square $=67.9 \%)$. By contrast, for companies that pollute less, law and regulations disclosure are more relevant.

The size factor included in the stock market model indicates that for smaller firms, social reporting and especially social mobilization and social control are positively related to the market value and improve the model quality $(\mathrm{R} 2=64.9 \%)$.

The market to book model's results on contingency effects show that environmental disclosure and more precisely the factor "actual management of the environment" is positively related to the market to book ratio. By contrast, ROE and the law and regulations disclosure are relevant for low polluting firms. Social disclosure is also relevant for polluting firms and above all for smaller firms. For medium-sized enterprises, social disclosure, and more particularly the social control factor improves the quality of the model.

\section{Discussion}

This research has focused on the impact of social and environmental disclosure on the performance of firms, successively measured by market value and the market-to-book ratio. The regression results confirm hypotheses H1A and $\mathrm{H} 2 \mathrm{~A}$. The disclosure score of CSR and SD is positively associated with the performance of companies. The best model associated to a company's financial performance is the one that integrates the global disclosure score. Investors value companies that consider the social and environmental consequences of their business in a comprehensive, thorough manner. Disclosure is considered a global and coherent set of information by investors. They analyze environmental issues and social issues that relate to the social dimension of the organization. It is the CSR report as a whole that influences how investors ultimately conduct financial valuations.

The environmental communication score is integrated into a target of short-term financial performance and confirms 
hypothesis H1B. The score is positively correlated to market value. The research shows that environmental regulation, its appreciation and effective consideration, represents the dimension that influences significantly the financial performance of companies. Companies are valued better if they provide comprehensive regulatory and voluntary disclosures. Actions in favor of environmental security serve to boost investor sentiment. Moreover, the social score also has an impact on financial performance in the short and long-term, confirming hypothesis $\mathrm{H} 1 \mathrm{C}$ and $\mathrm{H} 2 \mathrm{C}$. This score is positively correlated to the market value and the "market-to-book" ratio. Investors give credit to social disclosure and they envision it as a source of value creation. These results complement the work of Margolis and Walsh (2002 and 2007) who established a link between social issues and a firm's financial performance.

The analysis based on contingency effects, sector and company size, indicates that for the most polluting companies, environmental action (resource conservation, remediation and management of the environment) is scrutinized by shareholders. They prefer to take into consideration these real managerial actions rather than companies' compliance with rules as a source of value creation in the future.

For companies that pollute less, social factors including the social steering axis represent the best indication of the future financial performance. The size factor included in the regression model indicates that, for smaller companies, the social score including "social steering" and "employee mobilization" are most valued by investors. For these companies, social disclosures represent an efficient way to report on the quality of their management. Regarding the market-to-book model, global and social information disclosure is perceived by investors as a long-term factor that influences financial performance. The informational effort made by the company regarding the quality of personnel management is enhanced by the market in the long-term, especially in companies with relatively small number of employees. These results confirm the work of Dhaliwal and alii (2011) in which they say companies experiencing better performances are more likely to publish information voluntarily. But the study does not confirm the work of Richardson and Welker (2001) who claimed that high social information disclosure increases the cost of equity and consequently decreases the firms' financial performance. However, Richardson and Welker (2001) focused on the quantitative aspect of social disclosure and its immediate impact on the cost of capital. They did not examine the content of the information disclosed (2001: 613) and the consistency of the social information delivered. The current study reveals the importance of the social dimension disclosed in accordance with the company strategy in order to assess the financial performance. The amount of information provided is not a factor of prime importance.

On the other hand, it is "the social control" factor that improves the explanatory power of model 2. The "social control" also establishes a close link between strategy, implementation of decisions, employee training and convergence with the CSR displayed. Investors also value the consistency between what is said and the implemented strategic practices. These results mark a significant difference with the work of Barth and McNichols (1994) who observed that stakeholders were satisfied with approximate, little and disparate information, to enhance the financial performance of companies.

Voluntary disclosure of combined social and environmental information offers useful information to investors because it limits information asymmetry and it gives an indication of the quality of business management. The results of this research also mark a slight difference with the work of Cormier, Ledoux and Magnan (2011). These results regarding French and European companies confirm the finding that social disclosure reinforces the information content of environmental disclosure for stock markets but there is no substitution effect as it was suggested by Cormier, Ledoux and Magnan in the Canadian context (2011). From the investors' point of view, social disclosure does not replace lack of environmental information. Investors indicate clearly that they regard in-depth information including social and environmental disclosure. When there is a consistent structure for social and environmental disclosure, investors react in a positive way.

\section{Conclusion}

The research results indicate that investors integrate the social and environmental disclosure of companies listed on Nyse-Euronext (SBF 120 Index) in a positive way: the environmental score has an effect on the short-term financial performance, whereas the social score has an effect on both the short and long-term financial performance. This research takes an innovative approach by measuring CSR and SD disclosure as a whole using the global variable score which improves the explanatory power of the model. These results challenge previous research that focused solely on one dimension of the relationship in an effort to understand the cost of capital or financial performance of companies.

The principal components made it possible to refine the analysis by identifying the main axes of communication and show that, as it was found in earlier studies, complying with environmental laws and regulations is a predominant factor much like the appropriateness of employees in company strategy. Ultimately, sustainable development reports, in addition to their intrinsic value, are meaningful for investors and offer relevant information. The research concludes with the relevance of global or multidimensional disclosure (both environmental and social) in keeping up with corporate strategy to explain a company's financial performance in the best possible way.

Finally, the results presented here make it possible to envision several different research paths to explain the link between CSR, SD and financial performance: the consideration of voluntary disclosures in addition to those presented 
in SD reports (from websites), a broadened study that includes a sample of international companies and also the effect of these disclosures on the cost of capital.

\section{References}

Aerts W., Cormier D., Magnan M. (2008), «Corporate Environmental disclosure, financial markets and the media: An international perspective«, vol. 64, ecological economics, issue 3 , p. 643-659.

Allouche J., Huault I., Schmidt G. (2004), «Responsabilité Sociale des Entreprises: la mesure détournée? », Actes du Colloque AGRH, 2004, basepub.dauphine.fr, p. 2389-2410.

Amir E., Lev B. (1996), «Value-relevance of non financial information: The wireless communication industry », Journal of Accountings and Economics, vol. 22, $\mathrm{n}^{\circ}$ 1, p.33-21.

André J-M., Husser J., Barbat G., Lespinet-najib V. (2011), «Le rapport de développement durable des entreprises françaises : Quelles perspectives pour les parties prenantes?», Revue Management et Avenir, $n^{\circ} 48, \mathrm{p} .42-56$.

Ball R., Kothari S.P., Robin A. (2000), «The effect of international institutional factors on properties on accounting earnings », Journal of Accounting and Economics, vol. 29, $\mathrm{n}^{\circ} 1$, p.1-52.

BARTHES, R. (1991). L'aventure sémiologique, Le Seuil Collection Points Essais, Paris, 162 p.

Barth M.E., McNichols M.F. (1994), «Estimation and market valuation of environmental liabilities relating to superfund sites », Journal of Accounting Research, vol. 32, n 1, p.177-191.

Botosan C.A., Plumlee M.A. (2002), «A re-examination of Disclosure Level and the Expected Cost of Equity Capital», Journal of Accounting Research, vol. 40, $\mathrm{n}^{\circ}$ 1, March 2002, p.21-40.

Botosan C.A. (2006), «Disclosure and the cost of capital: What do we know?», Accounting and Business Research, issue 36, p. 31-40.

Caroll A. (1979), «A Three-Dimensional Conceptual Model of Corporate Social Performance», Academy of Management Review, Vol. 4, n 4, p. 497-505.

Cazavan-Jeny A. (2004), "Le ratio market to book et la reconnaissance des immatériels - une reconnaissance du marché français », Comptabilité-Contrôle-Audit, vol. 10, n 2, p. 99-124.

Clarkson M.B. (1995), «A Stakeholder Framework for Analyzing and Evaluating Corporate Social Performance», Academy of Management Review, Vol. 20, $\mathrm{n}^{\circ}$ 1, p. 92-117.

Chen, W-P, Chung H., Lee C., Liao W.L. (2007), «Corporate governance and equity liquidity: analysis of $\mathrm{S}$ and $\mathrm{P}$ transparency and disclosure rankings », Corporate Governance-An international Review, vol. 15, No.4, p. 644-660.

Cormier D., Ledoux M-J., Magnan M. (2011), «The informational contribution of social and environmental disclosures for investors », Management Decision, Vol. 20, n 8 , p. 1276-1304.

Cormier D., Magnan M. (1999), «Corporate environmental disclosure strategies: determinants, costs and benefits », Accounting, Auditing and Finance Journal, Vol. 14, n 4, p. 429-451.

Cormier D., Magnan M. (2003), «Environmental reporting management: an European perspective», Journal of Accounting and Public policy, Vol. 22, n 1, p. 43-62.
Cormier D., Magnan M. (2007), «The revisited contribution of environmental reporting to investors' valuation of a firm's earnings: An international perspective », ecological economics, vol. 62, issues 3-4, May 2007, p. 613-626.

Cormier D., Magnan M. (2008), «Corporate environmental disclosure, financial markets and the media: An international perspective», vol. 64, p.643-659.

Cormier D., Ledoux M.J. And Magnan M., (2011), «The informational contribution of social and environmental disclosures for investors », Management Decision, Vol. 49, n 8, p. 1276-1304.

Dhaliwal D.S., Li O.Z., Tsang A., YANG Y.G. (2011), «Voluntary Nonfinancial Disclosure and the Cost of Equity Capital: The initiation of Corporate Social Responsibility Reporting», The Accounting Review, vol. 86, $\mathrm{n}^{\circ}$ 1, p. 59-100.

Dejean F., Martinez I. (2009a), «Environmental disclosure and the Cost of Equity: The French Case», Accounting in Europe, vol. $6, \mathrm{n}^{\circ} 1$, p. 57-80.

Dejean F., Martinez I. (2009b), «Communication environnementale des entreprises du SBF 120 : déterminants et conséquences sur le coût du capital actions », Comptabilité-Contrôle-Audit, Tome 15, Vol. 1, Juin 2009, p. 55-78.

Dejean F., Oxibar B. (2007), «Corporate social disclosure and legitimation strategy: a longitudinal study of Pechiney, XXXth Annual Congress of the European Accounting Association (EAA)», Lisbonne.

Demazière D., Dubar C. (1997), Analyser les entretiens biographiques, Essais et recherches Nathan, Paris, $350 \mathrm{p}$.

Fankel R.et LeE C. (1995), «Accounting Valuation, Market Expectation, and the Book market Effect, Working Paper, university of Michigan, $322 \mathrm{p}$.

FREEMAN R.E. (1984), Strategic Management: A stakeholder approach, Pitman Series in Business and Public Policy, Boston, $276 \mathrm{p}$.

FrEeman R.E., ReEd D.L. (1983), «Stockholders and Stakeholders: A new perspective on Corporate Governance», California Management Review, Vol. 25, No. 3, p. 88-106.

Guthrie J., PArker L.D. (1989), «Corporate Social reporting: a rebuttal of legitimacy theory», Accounting and Business Research, 19, $\mathrm{n}^{\circ} 76$, p. 343-52.

Husser, J., André, J. M., Barbat, G. and Lespinet-Najib, V. (2012), «CSR and sustainable development: are the concepts compatible?», Management of Environmental Quality: An International Journal, 23, $\mathrm{n}^{\circ}$ 6, 658-672.

Kochan T.A., Rubinstein S.A. (2000), «Towards a stakeholder theory of the firm: The Saturn Partnership», Organization Science, Vol. 11, n 4, p. 367-386.

Lev B., Sougiannis T. (1996), «The capitalization, amortization and value-relevance of $R \& D$ », Journal of Accountings and Economics vol. 21, ${ }^{\circ}$ 1, p. 107-139.

Maignan I., Ralston D. (2002), «Corporate Social Responsibility in Europe and the U.S. : Insights from Businesses' Self-presentations », Journal of International Business Studies, $3^{\text {rd }}$ Quarter, p. 497-514.

Maignan I., Ferrell (2003), «Nature of Corporate Responsibilities. Perspectives from American, French and German Consumers », Journal of Business Research, ${ }^{\circ}$ 56, p. 55-67.

Margolis J.D., Walsh J.P. (2002), «Misery Loves Companies: Rethinking Social Initiatives by Business?», Working Papers, Harvard Business School, December 16, 62 p. 
Margolis J.D., Elfenbein H.A., Walsh J.P. (2007), «Does it pay to be good? A meta-analysis and redirection of research on the relationship between corporate social and financial performance», Harvard University Working Paper, July, 79 p.

Mauléon F., Silva F. (2009), «États des lieux de la RSE et du développement durable en France», Revue Management \& Avenir, No. 23, p. 23-35.

Novethic (2009), Quelle place pour la mobilisation des salariés dans les rapports Développement durable des entreprises CAC 40?, Février 2009, 123 p.

OHLSON J. (1995), «Earnings, book values and dividends in security valuation», Contemporary Accounting Research, 11, p. 161-182.

ORIJ R. (2010), «Corporate social disclosures in the context of national cultures and stakeholder theory », Accounting, Auditing \& Accountability Journal, Vol. 23, n 7 , p. $868-889$.

Orlitzky M., Schmidt F.L., Rynes S.L. (2003), „Corporate social and Financial Performance: A Meta-Analysis», Organization Studies, March 2003, vol. 24, n 3, p. 403-441.

Patten D.M. (2002), «The relation between environmental performance and environmental disclosure: a research note», Accounting, Organizations and Society, $\mathrm{n}^{\circ}$ 27, p. 763-773.

Plumlee M., Brown D., Hayes R.M., Marshall S. (2010), «Voluntary Environmental Disclosure Quality and Firm Value: Further Evidence», Social Science Research Network, December 2010, $43 \mathrm{p}$

Poincelot E., Wegmann G. (2005), «Utilisation des critères non financiers pour évaluer ou piloter la performance: analyse théorique». Comptabilité-Contrôle-Audit, Vol. 11, No. 2, p. 109-125.

Pourtier F. (2004), «La publication d'informations financières volontaires: synthèse et discussions », Comptabilité-ContrôleAudit, Vol. 10, $\mathrm{n}^{\circ}$ 1, p. 79-102.

Richardson A.J., Welker M. (2001), «Social disclosure financial disclosure and the cost of capital », Accounting, Organizations and society, $\mathrm{n}^{\circ} 26$, p. 127-159.

Roman R., Hayibor S., Agle B. (1999), «The Relationship between Social and Financial Performance. Epainting a portrait», Business and Society, vol. 38, ${ }^{\circ}$ 4, p. 123-145.

ScotT T. (1994), «Incentives and disincentives for financial disclosure: voluntary disclosure of defined benefit pension plan information by Canadian firms », The Accounting Review, vol. $69, \mathrm{n}^{\circ} 1$, p. $26-43$.

Van Overfelt W., Deloof M., Vanstraelen A. (2010), «Determinants of Corporate Financial Disclosure in an Unregulated Environment: Evidence From the Early $20^{\text {th }}$ Century », European Accounting Review, Vol. 19, n 1, p. 7-34.

Verrechia R.E. (2001), «Essays on disclosure», Journal of Accounting and Economics, vol. 32, December, p. 97-180.

Wiseman J. (1982), «An evaluation of environmental disclosures made in corporate annual reports », Accounting, Organizations and Society, vol. 7, $\mathrm{n}^{\circ}$ 1, p.553-563.

Wolfe R., Putler D.S. (2002), «How tight are the ties that bind stakeholder groups?» Organization Science, Vol. 13, $\mathrm{n}^{\circ} 1$, p. 64-80. 


\section{APPENDIX 1A}

Grid of environmental disclosure analysis

\begin{tabular}{|c|c|c|c|c|c|c|c|}
\hline $\mathbf{N}^{\circ}$ & ITEM & Observation & PTS & Observation & PTS & Observation & PTS \\
\hline 1 & $\begin{array}{l}\text { Environmental } \\
\text { hazards }\end{array}$ & $\begin{array}{l}\text { No reference to the environmental } \\
\text { contingencies or less than } \\
3 \text { references - item described } \\
\text { in a very limited fashion }\end{array}$ & 1 & $\begin{array}{l}\text { Description of } 3 \text { environmental contingencies } \\
\text { Among them are: } \\
\text { - Provisions for environmental contingencies } \\
\text { - Future expenditure estimates } \\
\text { Equipment available to prevent these risks } \\
\text { - Financing for pollution control } \\
\text { - Reserves for expenses } \\
\text { - Environmental debts }\end{array}$ & 2 & $\begin{array}{l}\text { Description of more than } 3 \text { environmental } \\
\text { contingencies with quantification }\end{array}$ & 3 \\
\hline 2 & $\begin{array}{l}\text { Environmental } \\
\text { Law \& } \\
\text { Regulations }\end{array}$ & $\begin{array}{l}\text { Item treated in a very general } \\
\text { fashion }\end{array}$ & 1 & $\begin{array}{l}\text { Item treated with a specific method: } \\
\text { Litigation, fines, corrective actions }\end{array}$ & 2 & $\begin{array}{l}\text { Item treated with a specific method } \\
\text { and with quantification }\end{array}$ & 3 \\
\hline 3 & $\begin{array}{l}\text { Pollution } \\
\text { Treatment }\end{array}$ & $\begin{array}{l}\text { No mention about Pollution } \\
\text { Treatment }\end{array}$ & 1 & $\begin{array}{l}\text { Item treated explicitly for two subcategories: } \\
\text { - information on air pollution emission } \\
\text { - standards compliance } \\
\text { - noise and odor then solid waste }\end{array}$ & 2 & $\begin{array}{l}\text { Item treated explicitly for } 2 \text { subcategories } \\
\text { with a specific method and with } \\
\text { quantification }\end{array}$ & 3 \\
\hline 4 & $\begin{array}{l}\text { Natural } \\
\text { Resource } \\
\text { Conservation }\end{array}$ & $\begin{array}{l}\text { No mention about Natural } \\
\text { Resource Conservation }\end{array}$ & 1 & $\begin{array}{l}\text { Management of natural resource } \\
\text { conservation using a specific method } \\
\text { with a precise schema }\end{array}$ & 2 & $\begin{array}{l}\text { Management of natural resource } \\
\text { conservation using a specific method } \\
\text { with a precise schema and } \\
\text { quantification on the long term range }\end{array}$ & 3 \\
\hline 5 & Site Renovation & No mention about site renovation & 1 & Cost description or renovation efforts & 2 & $\begin{array}{l}\text { Cost description or renovation efforts } \\
\text { and quantification on the long term range }\end{array}$ & 3 \\
\hline 6 & $\begin{array}{l}\text { Environmental } \\
\text { Management }\end{array}$ & $\begin{array}{l}\text { Lack of information on the } \\
\text { environmental audit or lack of envi- } \\
\text { ronmental management objectives }\end{array}$ & 1 & $\begin{array}{l}\text { Existence of objectives or ISO standards } \\
\text { or internal audit }\end{array}$ & 2 & $\begin{array}{l}\text { Existence of objectives or ISO standards } \\
\text { or internal audit with quantification }\end{array}$ & 3 \\
\hline
\end{tabular}


APPENDIX 1B

Grid of Social Disclosure analysis

\begin{tabular}{|c|c|c|c|c|c|c|c|}
\hline $\mathbf{N}^{\circ}$ & ITEM & Observation & PTS & Observation & PTS & Observation & PTS \\
\hline 1 & $\begin{array}{l}\text { Positioning of employees } \\
\text { related to the business strategy } \\
\text { (President's editorial) }\end{array}$ & No: no information provided & 1 & $\begin{array}{l}\text { Simple reference to the necessity of } \\
\text { engaging the employees without a } \\
\text { budget or a timeline }\end{array}$ & 2 & $\begin{array}{l}\text { Reference to the importance } \\
\text { of employee awareness or } \\
\text { professional training or } \\
\text { remuneration to guarantee the } \\
\text { employees involvement in the } \\
\text { business strategy }\end{array}$ & 3 \\
\hline 2 & Awareness actions & $\begin{array}{l}\text { There is no mention of such } \\
\text { efforts }\end{array}$ & 1 & $\begin{array}{l}\text { Yes, but limited to the following } \\
\text { factors: length, one group } \\
\text { (population ), or one theme }\end{array}$ & 2 & $\begin{array}{l}\text { with multiple themes and multiple } \\
\text { groups }\end{array}$ & 3 \\
\hline 3 & Training and Education efforts & $\begin{array}{l}\text { There is no mention of any } \\
\text { action (static verb or statement } \\
\text { markers only) }\end{array}$ & 1 & $\begin{array}{l}\text { Yes, but limited to just a few groups } \\
\text { or limited to some specifically } \\
\text { themed educational training } \\
\text { programs }\end{array}$ & 2 & $\begin{array}{l}\text { with multiple themes and multiple } \\
\text { groups }\end{array}$ & 3 \\
\hline 4 & $\begin{array}{l}\text { Management efforts targeting } \\
\text { a fixed change in CSR politics: } \\
\text { motivation, actual system for } \\
\text { the exchange of good practices }\end{array}$ & $\begin{array}{l}\text { There is no mention of any } \\
\text { action (static verb or statement } \\
\text { markers only) }\end{array}$ & 1 & $\begin{array}{l}\text { Yes, but limited to just a few groups } \\
\text { or limited to some specifically } \\
\text { themed educational training } \\
\text { programs }\end{array}$ & 2 & $\begin{array}{l}\text { with multiple themes and multiple } \\
\text { target groups fixed in time (not } \\
\text { only limited to short term) }\end{array}$ & 3 \\
\hline 5 & $\begin{array}{l}\text { CSR integrated into HR } \\
\text { management: recruitment, } \\
\text { evaluation, remuneration }\end{array}$ & $\begin{array}{l}\text { There is no mention of any } \\
\text { action }\end{array}$ & 1 & $\begin{array}{l}\text { Yes, but only partially ( not the } 3 \\
\text { mentioned themes) no temporal } \\
\text { perspective }\end{array}$ & 2 & $\begin{array}{l}\text { with the presence of } 3 \text { themes } \\
\text { linked to CSR in the long term }\end{array}$ & 3 \\
\hline 6 & $\begin{array}{l}\text { Realization of employee } \\
\text { mobilization - witnesses }\end{array}$ & $\begin{array}{l}\text { No example of the mobilized } \\
\text { employee's experience in CSR }\end{array}$ & 1 & $\begin{array}{l}\text { Employee photos and tools created } \\
\text { by and put into action by employees }\end{array}$ & 2 & $\begin{array}{l}\text { Reports of CSR's impact } \\
\text { Developed and actual testimonies }\end{array}$ & 3 \\
\hline
\end{tabular}




\section{APPENDIX 2}

\section{Example of qualitative data collection from L'Oréal ( sample of data collection)}

\begin{tabular}{|c|c|c|c|}
\hline \multicolumn{4}{|c|}{ Grid of environmental disclosure analysis: Total environmental score: $15 \mathrm{pts}$} \\
\hline $\mathbf{N}^{\circ}$ & THEMES & Observations & PTS \\
\hline 1 & $\begin{array}{l}\text { Environmental } \\
\text { hazards } \\
\text { Ref page } 46\end{array}$ & $\begin{array}{l}\text { Some major issues of sustainability such as fair trade, fair return, access to genetic } \\
\text { resources, respect traditional knowledge, the risks to health and the environment require } \\
\text { a special dialogue with suppliers, associations, NGOs and communities living near areas } \\
\text { where raw materials are harvested }\end{array}$ & 2 pts \\
\hline 2 & $\begin{array}{l}\text { Environmental } \\
\text { Law \& } \\
\text { Regulations } \\
\text { Ref page } 19\end{array}$ & $\begin{array}{l}\text { We had a strong year of environmental performance in } 2007 \text { attaining most of our targets } \\
\text { and achieving improvements in most of our key performance indicators (Kpis) overall. } \\
\text { We achieved absolute reductions in energy use, water, greenhouse gases, sulphur dioxide, } \\
\text { volatile organic compounds. }\end{array}$ & 3 pts \\
\hline 3 & $\begin{array}{l}\text { Pollution } \\
\text { Treatment } \\
\text { Ref page } 20\end{array}$ & $\begin{array}{l}\text { In the development and validation of alternative methods, L'Oréal has developed } \\
\text { solutions for the control and treatment against pollution sites identified as highly } \\
\text { polluting the planet. }\end{array}$ & 3 pts \\
\hline 4 & $\begin{array}{l}\text { Natural } \\
\text { Resource } \\
\text { Conservation } \\
\text { Ref page } 22\end{array}$ & $\begin{array}{l}\text { Exceeding our goal of reducing water consumed in factories by } 3 \% \text { per unit of finished } \\
\text { product, achieving } 3.4 \% \text {. We reduced total water use by } 6.9 \% \text {. } \\
\text { - Exceeding our goal of reducing our total Co } 2 \text { emissions by } 2 \% \text {, achieving a } 6.6 \% \\
\text { reduction. }\end{array}$ & 3 pts \\
\hline 5 & $\begin{array}{l}\text { Site Renovation } \\
\text { Ref page } 21\end{array}$ & $\begin{array}{l}\text { Three sites are regulated by the requirements of the European seveso directive as "Grand } \\
\text { seveso" for the control of major accident hazards, due to the storage of chemicals or } \\
\text { flammable gases. }\end{array}$ & 2 pts \\
\hline 6 & $\begin{array}{l}\text { Environmental } \\
\text { Management } \\
\text { Ref page } 20\end{array}$ & $\begin{array}{l}\text { L'Oréal is committed to reducing our environmental impact and resource use through } \\
\text { absolute reductions. Where this is not practicable, we aim for greater eco-efficiency and } \\
\text { use of more environmentally friendly approaches. We are also committed to a healthy and } \\
\text { safe workplace. }\end{array}$ & $2 \mathrm{pts}$ \\
\hline
\end{tabular}




\section{APPENDIX 2 (continued)}

Grid of social disclosure analysis: Total social score: $14 \mathrm{pts}$

\begin{tabular}{|c|c|c|c|}
\hline $\mathbf{N}^{\circ}$ & THEMES & Observations & PTS \\
\hline 1 & $\begin{array}{l}\text { Positioning } \\
\text { of employees } \\
\text { related to } \\
\text { the business } \\
\text { strategy } \\
\text { Ref: page } 3\end{array}$ & $\begin{array}{l}\text { In human resources, we took a further step to ensure that we have a clear and unified } \\
\text { policy on hiring, induction, training, remuneration and career development across } \\
\text { the world with the launch of the "L'Oréal \& Me" program, once again demonstrating } \\
\text { our ambition to be a great place to work. Our work on diversity goes on: nearly } 5,000 \\
\text { managers have now attended the diversity training course set up in 2006, half of our } 23 \\
\text { international brands are headed by women. }\end{array}$ & 2 pts \\
\hline 2 & $\begin{array}{l}\text { Awareness } \\
\text { actions } \\
\text { Ref: page } 8\end{array}$ & $\begin{array}{l}\text { L'Oréal's HR policy aims to establish a lasting and productive relationship with } \\
\text { employees based on trust and mutual respect by: an active recruitment policy aiming } \\
\text { to expand the group's culture, diversity and skills, developed through partnerships with } \\
\text { universities worldwide. }\end{array}$ & 3 pts \\
\hline 3 & $\begin{array}{l}\text { Training and } \\
\text { Education } \\
\text { efforts } \\
\text { Ref page } 3 \\
\text { Ref page } 10\end{array}$ & $\begin{array}{l}\text { Our work on diversity goes from strength to strength: nearly 5,000 managers have now } \\
\text { attended the diversity training course set up in 2006, and half of our } 23 \text { international } \\
\text { brands are headed by women. And by reducing the accident rate in our factories and } \\
\text { warehouses by } 18 \% \text {, we came closer to our long term aim of zero accidents. }\end{array}$ & 2 pts \\
\hline 4 & $\begin{array}{l}\text { Management: } \\
\text { change in CSR } \\
\text { page } 57\end{array}$ & $\begin{array}{l}\text { The responsibilities of the Group Director of Ethics are as follows: } \\
\text { - promote and integrate ethical best practices across the group, including through training } \\
\text { and advice... }\end{array}$ & 3 pts \\
\hline 5 & $\begin{array}{l}\text { CSR integrated } \\
\text { into HR } \\
\text { management } \\
\text { Ref page } 59\end{array}$ & $\begin{array}{l}\text { At L'Oréal, remuneration policy reflects employee contributions to the company's } \\
\text { development and is geared toward attracting and retaining talented individuals. While } \\
\text { broadly applied to all group employees, it does vary according to the job and level of } \\
\text { responsibility. All units have a remuneration policy based on a standard assessment } \\
\text { system applied worldwide which recognizes individual performance. }\end{array}$ & $2 \mathrm{pts}$ \\
\hline 6 & $\begin{array}{l}\text { Realization } \\
\text { of employee } \\
\text { mobilization - } \\
\text { witnesses } \\
\text { Ref page } 61\end{array}$ & $\begin{array}{l}\text { Employees have expressed particular satisfaction to work with talented people and enjoy } \\
\text { the excellent opportunities for training and skills development identified in a development } \\
\text { system performance }\end{array}$ & $2 \mathrm{pts}$ \\
\hline
\end{tabular}




\section{APPENDIX 3}

\section{Sample}

\begin{tabular}{|c|c|c|}
\hline Accor SA & JC Decaux SA & Television Francaise 1 \\
\hline Aeroports de Paris SA (ADP) & Lafarge SA & Thales (Ex Thomson Csf) \\
\hline Air France-KLM & Lagardere & Total SA \\
\hline Air Liquide SA & LeGrand Holding SA & Trigano SA \\
\hline Alcatel-Lucent & LVMH & Ubisoft Entertainment SA \\
\hline Alstom SA & M6 MetropoleTelevision & Valeo SA \\
\hline Alten SA & Maurel Et Prom & Vallourec SA \\
\hline Altran Technologies SA & Mercialys SA & Veolia Environnement SA \\
\hline ArcelorMittal S.A. & Mersen S.A. & Vinci SA \\
\hline AREVA SA & Michelin & Vivendi \\
\hline Arkema SA & Neopost SA & Zodiac Aerospace \\
\hline Assystem & Nexans SA & \\
\hline Atos SA & NRJ Group SA & \\
\hline Beneteau SA & Oreal (L') & \\
\hline Bonduelle SA & Orpea SA & \\
\hline Bourbon SA & Pages Jaunes & \\
\hline Bouygues SA & Pernod Ricard SA & \\
\hline Bureau Veritas & Peugeot SA & \\
\hline Cap Gemini SA & Pierre \& Vacances & \\
\hline Carrefour SA & PPR SA & \\
\hline Casino Guichard SA & Publicis Groupe SA & \\
\hline CGG Veritas & Remy Cointreau & \\
\hline Ciments Francais SA & Renault SA & \\
\hline Club Mediterranee & Rexel SA & \\
\hline Danone S.A. & Rhodia SA & \\
\hline Dassault Systemes & Rodriguez Group SA & \\
\hline Derichebourg & Sanofi SA & \\
\hline Eads & Schneider Electric SA & \\
\hline Eiffage SA & SEB SA & \\
\hline Electricite de France & SES SA & \\
\hline Eramet SA & Societe BIC & \\
\hline Essilor Intl & Sodexo SA & \\
\hline Eutelsat Communications SA & Soitec & \\
\hline Faurecia SA & Sperian Protection SA & \\
\hline Groupe Eurotunnel & Spir Communication SA & \\
\hline Haulotte Group & Stallergenes SA & \\
\hline Havas SA & Steria (Groupe) & \\
\hline Hermes International & Stmicroelectronics & \\
\hline Iliad SA & Suez Environnement & \\
\hline Imerys SA & Technicolor & \\
\hline Ingenico SA & Technip SA & \\
\hline Ipsos SA & Teleperformance SA & \\
\hline
\end{tabular}




\section{APPENDIX 4}

Model 1 Results: Environmentally - sensitive and non sensitive industries

\begin{tabular}{|c|c|c|c|c|c|}
\hline \multicolumn{6}{|c|}{ Model 1: High-polluting firms } \\
\hline \multirow{2}{*}{$\begin{array}{l}\text { Y: MVEs } \\
\text { Obs n = 46 }\end{array}$} & \multicolumn{5}{|c|}{ Coefficient estimation (p-value) } \\
\hline & Equation 1a & Equation 1b & Equation 1c & Equation 1d & Equation 1e \\
\hline $\mathrm{C}$ (constant) & $-8.707(0.755)$ & $6.212(0.806)$ & $0.392(0.990)$ & $12.337(0.647)$ & $42.210(0.0 .108)$ \\
\hline BVS & $0.447 *(0.001)$ & $0.427 *(0.002)$ & $0.452 *(0.002)$ & $0.433 *(0.005)$ & $0.373 *(0.005)$ \\
\hline EPS & $1.991 *(0.000)$ & $1.983 *(0.000)$ & $1.953 *(0.000)$ & $1.990 *(0.000)$ & $2.382 *(0.000)$ \\
\hline SGLOB & $1.425 * * *(0.058)$ & & & & \\
\hline SENVT & & $2.272 * *(0.034)$ & & & \\
\hline SSOC & & & $1.096(0.441)$ & & \\
\hline LTA & $-0.742(0.637)$ & $-1.181(0.462)$ & $-0.026(0.987)$ & $0.076(0.963)$ & $-1.808(0.256)$ \\
\hline F1SOC & & & & $0.596(0.844)$ & \\
\hline F2SOC & & & & $1.394(0.538)$ & \\
\hline F1ENVT & & & & & $6.086 *(0.005)$ \\
\hline F2ENVT & & & & & $-0.720(0.101)$ \\
\hline $\mathrm{R}^{2}$ & $64.20 \%$ & $65 \%$ & $61.40 \%$ & $61.30 \%$ & $67.90 \%$ \\
\hline $\mathrm{R}^{2}$ adj & $60.70 \%$ & $61.60 \%$ & $57.70 \%$ & $56.40 \%$ & $63.90 \%$ \\
\hline Fisher (p-value) & $18.377(0.000)$ & $19.032(0.000)$ & $16.327(0.000)$ & $12.661(0.000)$ & $17.119(0.000)$ \\
\hline Durbin-Watson & 2.234 & 2.2 & 2.27 & 2.277 & 2.215 \\
\hline
\end{tabular}

Model 1: Low-polluting firms

\begin{tabular}{|c|c|c|c|c|c|}
\hline Obs $n=57$ & Equation 1a & Equation 1b & Equation 1c & Equation 1d & Equation 1e \\
\hline $\mathrm{C}$ (constant) & $-63.09 * *(0.033)$ & $-40.991(0.145)$ & $-56.5 * * *(0.057)$ & $-22.365(0.387)$ & $-13.312(0.624)$ \\
\hline BVS & $0.531 *(0.000)$ & $0.465 *(0.002)$ & $0.544 *(0.001)$ & $0.544 *(0.001)$ & $0.484 *(0.002)$ \\
\hline EPS & $0.137(0.545)$ & $0.168(0.475)$ & $0.144(0.533)$ & $0.137(0.550)$ & $0.203(0.396)$ \\
\hline SGLOB & $1.955 *(0.006)$ & & & & \\
\hline SENVT & & $2.176^{* * *}(0.055)$ & & & \\
\hline SSOC & & & $2.706 * *(0.018)$ & & \\
\hline LTA & $2.394(0.173)$ & $2.405(0.187)$ & $2.638(0.140)$ & $2.520(0.157)$ & $2.095(0.262)$ \\
\hline F1SOC & & & & $2.825(0.166)$ & \\
\hline F2SOC & & & & $5.525 * *(0.019)$ & \\
\hline F1ENVT & & & & & $2.156(0.470)$ \\
\hline F2ENVT & & & & & $4.520 * * *(0.057)$ \\
\hline $\mathrm{R}^{2}$ & $35.90 \%$ & $30.90 \%$ & $33.40 \%$ & $35.70 \%$ & $31.80 \%$ \\
\hline $\mathrm{R}^{2}$ adj & $31 \%$ & $25.60 \%$ & $28.30 \%$ & $29.40 \%$ & $25.10 \%$ \\
\hline Fisher (p-value) & $7.282(0.000)$ & $5.821(0.001)$ & $6.527(0.000)$ & $5.666(0.000)$ & $4.761(0.001)$ \\
\hline Durbin-Watson & 1.73 & 1.714 & 1.1805 & 1.937 & 1.754 \\
\hline
\end{tabular}

${ }^{*}$ significant at the $1 \%$ level; ${ }^{* *}$ significant at the $5 \%$ level; ${ }^{* * *}$ significant at the $10 \%$ level

MVES: Market value of equity per share; BVS: Book value per share; EPS: Earnings per share; SENVT: Environmental reporting score; SSOC: Social reporting score; SGLOB:Global reporting score; ITA: Natural log of total assets; F1SOC: Social Mobilization; F2SOC: Social Control; F1ENVT: Actual management of the environment; F2ENV: Law and regulations disclosure 


\section{APPENDIX 5}

Results model 1 - Firm size (number of employees)

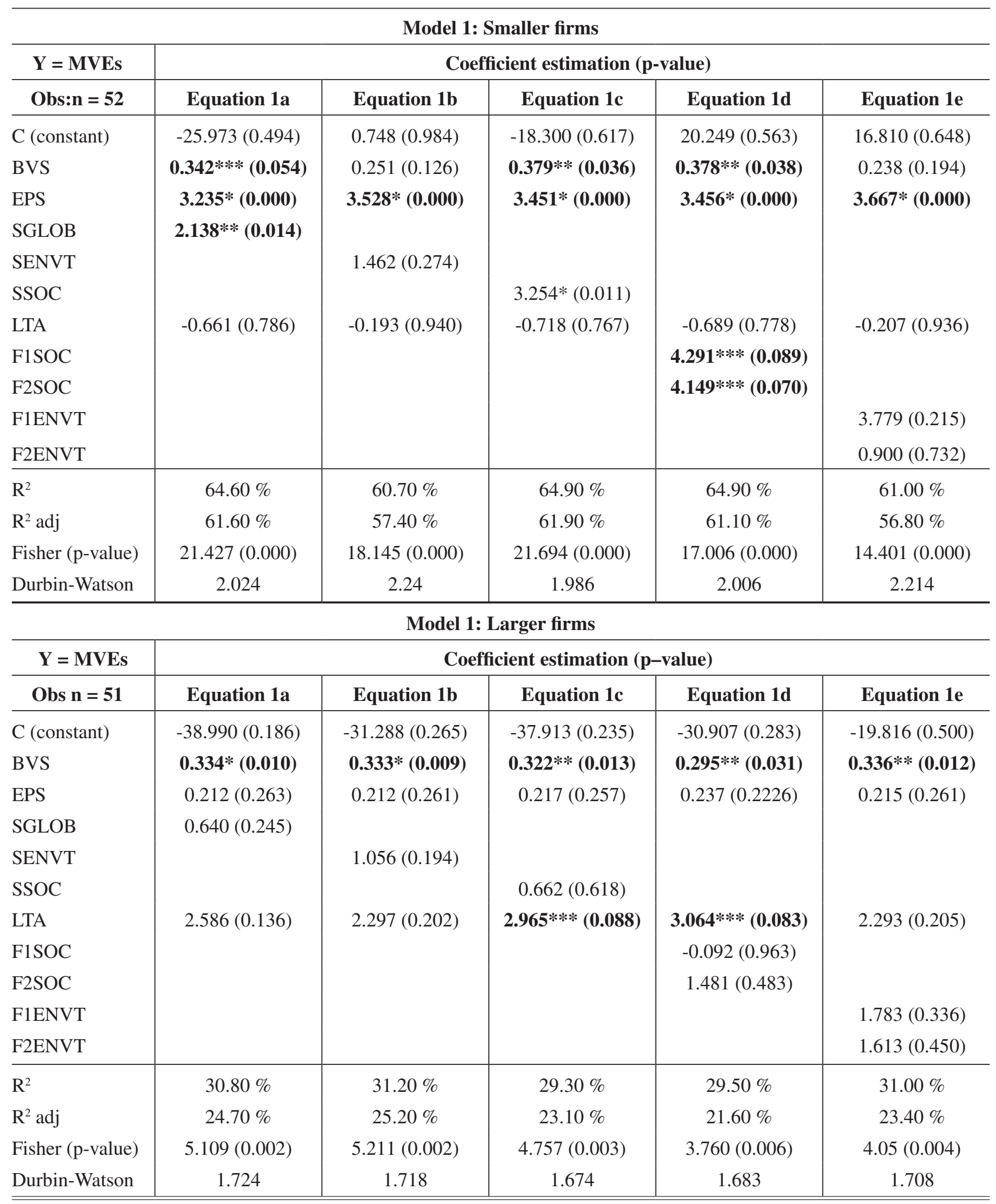

${ }^{*}$ significant at the $1 \%$ level; ${ }^{* *}$ significant at the $5 \%$ level; ${ }^{* * *}$ significant at the $10 \%$ level.

MVES: Market value of equity per share; BVS: Book value per share; EPS: Earnings per share; SENVT: Environmental reporting score; SSOC: Social reporting score; SGLOB: Global reporting score; ITA: Natural log of total assets; F1SOC: Social Mobilization; F2SOC: Social Control; F1ENVT: Actual management of the environment; F2ENV: law and regulations disclosure. 


\section{APPENDIX 6}

Market to book model (model 2) - Environmentally-sensitive and non sensitive industries

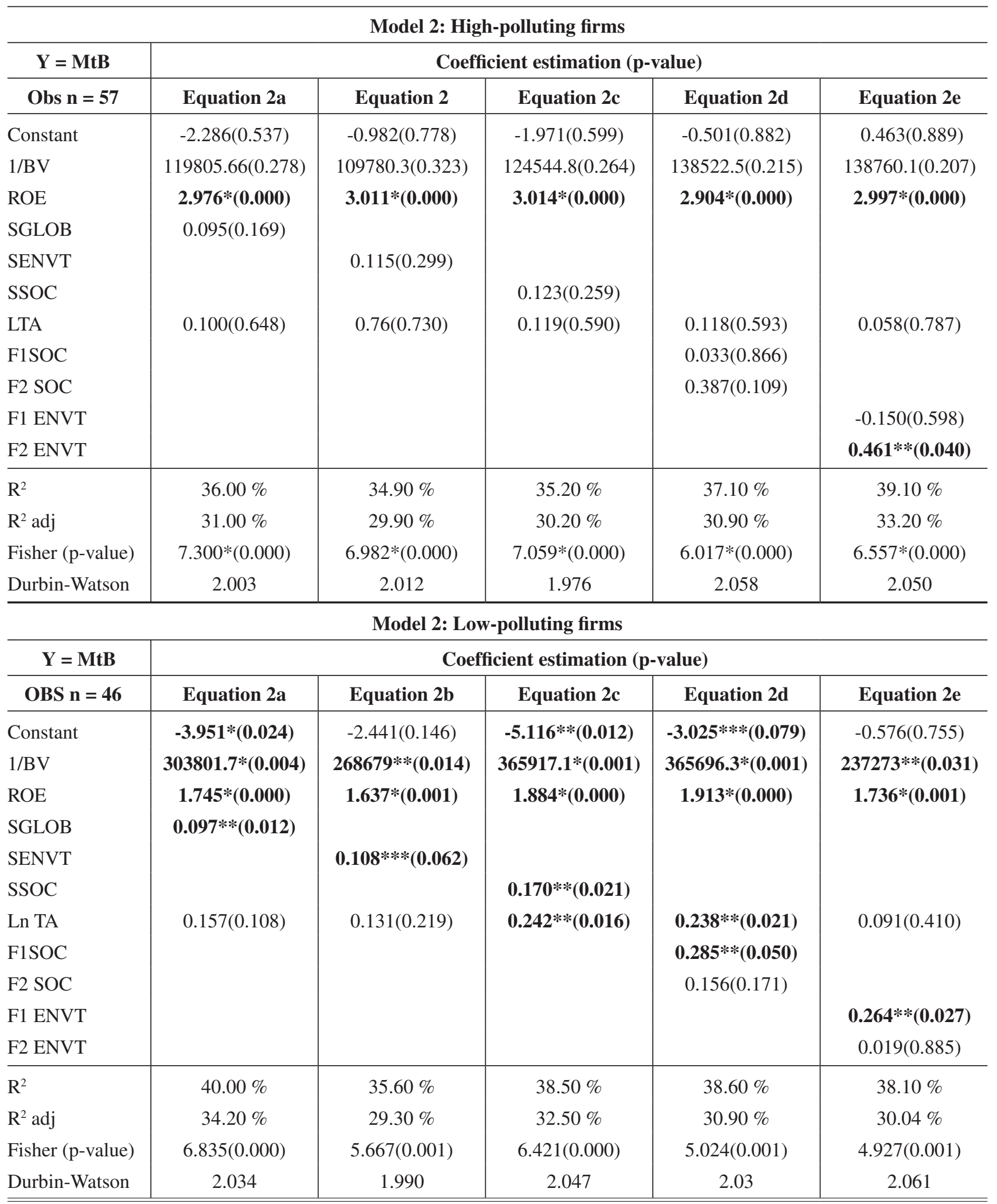

${ }^{*}$ significant at the $1 \%$ level; ${ }^{* *}$ significant at the coefficient $5 \%$ level; ${ }^{* *}$ significant at the $10 \%$ level.

MTB: Price to book ratio; BV: Book value of equity; ROE: return on equity; SENVT: Environmental reporting score; SSOC: Social reporting score; SGLOB: Global reporting score; lTA: Natural log of total assets; F1SOC: Social Mobilization; F2SOC: Social Control; F1ENVT: Actual management of the environment; F2ENV: law and regulations disclosure 


\section{APPENDIX 7}

Market to book model model 2) - Firm size (number of employees)

\begin{tabular}{|c|c|c|c|c|c|}
\hline \multicolumn{6}{|c|}{ Model 2 - Smaller firms } \\
\hline \multirow{2}{*}{$\begin{array}{c}\mathrm{Y}=\mathrm{MtB} \\
\text { OBS n = 52 }\end{array}$} & \multicolumn{5}{|c|}{ Coefficient estimation (p-value) } \\
\hline & Equation 2a & Equation 2b & Equation 2c & Equation 2d & Equation 2e \\
\hline Constant & $-4.085(0.330)$ & $-2.320(0.567)$ & $-5.925(0.150)$ & $-3.383(0.385)$ & $-2.898(0.488)$ \\
\hline $1 / \mathrm{BV}$ & $266135 *(0.008)$ & $272135 *(0.008)$ & $295736.2 *(0.003)$ & $301514 *(0.003)$ & $268590 * *(0.010)$ \\
\hline ROE & $7.508 *(0.000)$ & $7.844 *(0.000)$ & $2.751 *(0.000)$ & $7.726 *(0.000)$ & $7.898 *(0.000)$ \\
\hline SGLOB & $0.084(0.231)$ & & & & \\
\hline SENVT & & $-0.06(0.572)$ & & & \\
\hline SSOC & & & $0.228 *(0.021)$ & & \\
\hline LTA & $0.172(0.518)$ & $0.216(0.430)$ & $0.231(0.910)$ & $0.244(0.349)$ & $0.211(0.448)$ \\
\hline F1SOC & & & & $0.283(0.148)$ & \\
\hline F2 SOC & & & & $0.300 * * *(0.089)$ & \\
\hline F1 ENVT & & & & & $-0.083(0.738)$ \\
\hline F2 ENVT & & & & & $-0.115(0.581)$ \\
\hline $\mathrm{R}^{2}$ & $60.60 \%$ & $59.60 \%$ & $63.80 \%$ & $63.70 \%$ & $59.70 \%$ \\
\hline $\mathrm{R}^{2}$ adj & $57.20 \%$ & $56.20 \%$ & $60.70 \%$ & $59.7 \%$ & $55.30 \%$ \\
\hline Fisher (p-value) & $18.048(0.000)$ & $12.341(0.000)$ & $20.677(0.000)$ & $16.110(0.000)$ & $13.603(0.000)$ \\
\hline Durbin-Watson & 1.921 & 2.041 & 1.738 & 1.727 & 2.035 \\
\hline
\end{tabular}

Model 2 - Larger firms

\begin{tabular}{|c|c|c|c|c|c|}
\hline \multirow{2}{*}{$\begin{array}{c}\mathrm{Y}=\mathrm{MTB} \\
\text { Obs n = 51 }\end{array}$} & \multicolumn{5}{|c|}{ Coefficient estimation (p-value) } \\
\hline & Equation 2a & Equation 2b & Equation 2c & Equation 2d & Equation $2 \mathrm{e}$ \\
\hline Constant & $-1.249(0.472)$ & $-0.556(0.740)$ & $-1.400(0.462)$ & $-0.685(0.690)$ & $0.340(0.847)$ \\
\hline $1 / \mathrm{BV}$ & $89302.10(0.359)$ & $82214.30(0.401)$ & $106269.74(0.282)$ & $107392.3(0.278)$ & $75386.1(0.470)$ \\
\hline ROE & $1.240 *(0.001)$ & $1.253 *(0.01)$ & $1.212 *(0.001)$ & $1.223 *(0.001)$ & $1.265 *(001)$ \\
\hline SGLOB & $0.052 * * *(0.094)$ & & & & \\
\hline SENVT & & $0.081 * * *(0.089)$ & & & \\
\hline SSOC & & & $0.066(0.284)$ & & \\
\hline Ln TA & $0.076(0.451)$ & $0.053(0.610)$ & $0.112(0.273)$ & $0.117(0.255)$ & $0.052(0.624)$ \\
\hline F1SOC & & & & $0.044(0.680)$ & \\
\hline F2 SOC & & & & $0.161(0.171)$ & \\
\hline F1 ENVT & & & & & $0.161(0.147)$ \\
\hline F2 ENVT & & & & & $0.096(0.416)$ \\
\hline $\mathrm{R}^{2}$ & $38.00 \%$ & $38.10 \%$ & $35.60 \%$ & $36.80 \%$ & $38.10 \%$ \\
\hline $\mathrm{R}^{2}$ adj & $32.60 \%$ & $32.70 \%$ & $30.00 \%$ & $29.80 \%$ & $31.20 \%$ \\
\hline Fisher (p-value) & 7.034(0.000) & $7.067(0.000)$ & $6.369(0.000)$ & $5.248(0.001)$ & $5.545(0.000)$ \\
\hline Durbin-Watson & 1.572 & 1.595 & 1.479 & 1.516 & 1.614 \\
\hline
\end{tabular}

${ }^{*}$ significant at the $1 \%$ level; ${ }^{* *}$ significant at the $5 \%$ level; ${ }^{* * *}$ significant at the $10 \%$ level.

MTB: Price to book ratio; BV: Book value of equity; ROE: return on equity; SENVT: Environmental reporting score; SSOC: Social reporting score; SGLOB: Global reporting score; ITA: Natural log of total assets; F1SOC: Social Mobilization; F2SOC: Social Control; F1ENVT: Actual management of the environment; F2ENV: Law and regulations disclosure 